\title{
The Congressional Influence on the CFIUS Review and Its Implication to China
}

\author{
Chanting CHEN \\ Business School, East China University of Political Science and Law, Shanghai, China
}

\begin{abstract}
China is interested in U.S. foreign investment national security review system for more and more investors start to do business in the U.S. As the legislator and supervisor, Congress plays an important part in the U.S. CFIUS review process. This paper focuses on the congressional role in the development of the national security review system and its influence on Chinese investment in U.S. The paper is intended to let Chinese entrepreneurs be more familiar with Congressional role in the CFIUS review by the method of case study, so as to help them be prepared for investing in the U.S.
\end{abstract}

KEYWORD: Congressional Influence, CFIUS Review, Foreign Investment, U.S., China

\section{INTRODUCTION}

The U.S. and China are the two biggest economies in the world and also two of the most popular host countries for foreign investment according to the 2014 A.T. Kearney Foreign Direct Investment (FDI) Confidence Index.[1] The year of 2014 witnessed a rapid increase of Chinese FDI in the U.S. market. Because of the development of Chinese economy and the "go abroad" support from the central government and local governments, Chinese investment in the U.S. is expected to rise in the coming years.

From the other point of view, both governments and entrepreneurs in China are much concerned over the foreign investment national security review conducted by the Committee on Foreign Investment in the United States (CFIUS), which had discouraged or scared away many attempted investment from China. The involvement of Congress in the review process makes the situation more complicated. Many attempted transactions are aborted due to Congressional objections. This comment will review Congressional power in the CFIUS review process and Congressional reactions to Chinese investment. Empirical study on Congressional role in the CFIUS review process is worthwhile for Chinese entrepreneurs to start their investment journey in the U.S.
2 THE DEVELOPMENT OF THE U.S. FOREIGN INVESTMENT NATIONAL SECURITY REVIEW SYSTEM IS WITH CONGRESSIONAL INVOLVEMENT.

Though the President and CFIUS conduct the foreign investment national security review, Congress plays an important role in the process. The statutory role in the CFIUS review for Congress is to supervise administrative implementation of the review. Practically, however, Congress tries to influence the outcome of the CFIUS review with political pressure most of the time, usually by threatening to pass legislation specifically blocking the transaction.[2] The foreign investment national security review system in the U.S. has been developed along with Congressional influence.

\subsection{Congress Made the Exon-Florio Amendment to Lay Legal Foundation for the CFIUS Review}

The President Ford Announced Executive Order 11858 to establish CFIUS in the year 1975. According to the Executive Order, CFIUS was set up specifically for supervising the influence of the inbound foreign investment to the U.S. economy and for helping government implement foreign investment related policies. The Order originally did not delegate CFIUS the power to conduct national security review to foreign investment.[3] It was after Sir James Goldsmith's hostile takeover of Goodyear Corporation and Fujitsu Ltd.'s attempt acquisition of the Fairchild Semi-conductor Corporation that 
Congress concluded that it was necessary to have an additional statutory authority for suspending FDI. Congress therefore speeded up drafting a special regulation for evaluating the influence of foreign Mergers and Acquisitions (M\&As) to the country's security. The regulation is widely known as the Exon-Florio Amendment. It was passed into law under the Omnibus Trade and Competitiveness Act of 1988 and amended Section721 of Defense Production Act of 1950. The Amendment for the first time authorizes the President to take appropriate measures to disrupt suspicious takeovers that might threaten U.S. national security. President Reagan then announced the Executive Order 12661 to delegate the national review authority to CFIUS. The Amendment, together with the Executive Order, lays the foundation for CFIUS to substantially supervise the inbound M\&As.

What is the opinion of the President to a covered transaction? How does the President reach the conclusion? These questions belong to political issues. "[T]he courts lack jurisdiction over political decisions that are by their nature committed to the political branches to the exclusion of the judiciary."[4] Accordingly, the Presidential decision in the CFIUS review is not subject to judicial review. Congress therefore wrote its supervision power in the review process into the Amendment. The Amendment asks the President and CFIUS to transmit a report every four years. The report should evaluate "whether there is credible evidence of a coordinated strategy by one or more countries or companies to acquire United States companies involved in research, development, or production of critical technologies for which the United States is a leading producer" and "whether there are industrial espionage activities directed or directly assisted by foreign governments against private United States companies aimed at obtaining commercial secrets related to critical technologies.’[5]

\subsection{Congressional Dissatisfaction with CFIUS Review in the Thomson-CSF vs. LTV \\ Transaction Led to the Enactment of the Byrd Amendment.}

Congress later amended the Exon-Florio Amendment as part of the National Defense Authorization Act for Fiscal Year 1993, which was usually called as the Byrd Amendment. Congress introduced the Byrd Amendment because of its dissatisfaction with CFIUS performance when reviewing Thomson-CSF's acquisition of LTV Defense \& Aerospace Corporation's missile division. ${ }^{1}$

The LTV Defence \& Aerospace Corporation is a Dallasbased corporation, and once was the third largest steel manufacturer in the U.S., supplying steel products to the automotive,
Thomson-CSF's acquisition aroused wide concerns. Thomson-CSF had governmental background. The manufacturer, whose main products were on-board electronics for missiles and fire control units, was $59.2 \%$ owned by the French government at that time.[6] Besides, the LTV was considered as crucial to the nation's safety for it "held many defense contracts and was heavily involved in classified weapons systems"..[7] The case was the first time in U.S. history a major U.S. defense contractor would be sold to a foreign corporation. The transaction, if completed, would enable Thomson to "produce a complete missile system product," and inevitably transfer LTV's sensitive technology to the French government.[8]

CFIUS firstly disapproved of the transaction and recommended the President to block it when Thomson-CSF failed to reach an agreement on adequately restricting the outflow of sensitive technology.[9] CFIUS then approved the transaction after Thomson-CSF significantly restructured its acquisition.[10] According to Thomson-CSF's new acquisition plan, 94\% of LTV's missile division's interest would be acquired by the U.S.-based Loral Corporation while only $6 \%$ of the division's interest would be acquired by Thomson-CSF.[11] Yet the restructured proposal was still opposed by some key congressmen. Senate Finance Committee Chairman Lloyd Bentsen argued that shrinking ThomsonCSF's role to that of a minority partner would not reduce concerns of the foreign government's control of sensitive U.S. military technology, especially since the French government-controlled Thomson S.A. had a notorious record of selling military technologies to dangerous countries like Iraq. Senate Ernest F. Hollings, the Chairman of the Commerce Committee asserted that it was the military technology that Thomson sought, instead of other common business benefits.[12] Despite the prevalent opposition, the acquisition of LTV's aerospace and defense business by Thomson-CSF was still approved by the President.

Because of this, the LTV case was considered a sign that the U.S. government was inadequately protecting its key technologies and companies that were vital to national defense and global competitiveness. Unsatisfied Congress afterwards made the Byrd Amendment which created a mandatory review of M\&As that was controlled by or acting on behalf of a foreign government. Through this regulation, the Byrd Amendment created an additional standard of a separate review process focusing on the acquirer's government ownership. According to the Byrd Amendment, if a

appliance, construction, and other industries. The Handbook of Texas Online --- LTV Corporation, http://www.tsha.utexas.edu/handbook/online/articles/LL/epl2.h tml (last visited Nov. 17, 2007). 
foreign government is involved, the original "threatens to impair the national security" standard will be changed into the "could affect the national security" standard.[13] This regulation considerably lowers the threshold of national security for transactions related to a foreign government.

\subsection{Governmental Approval of the DP World Case Impelled Congress to Draft FINSA and Impose Stricter Censorship on the CFIUS Review.}

Dubai Ports World (DP World) voluntarily approached CFIUS before acquiring the Peninsular and Oriental Steam Navigation Company (P\&O) of the United Kingdom in mid-October 2005 to clear potential regulatory barriers. DP World then received permission from CFIUS and purchased P\&O for USD 7 billion in March 2006, with the promise to keep P\&O's headquarters in London. The CFIUS decision, however, contradicted Congressional opinion.

Congress considered the transaction to be detrimental to U.S. security because P\&O operated major U.S. port facilities in New York, New Jersey, Philadelphia, Baltimore, New Orleans, and Miami; two of the hijackers in the 9/11 events were UAE nationals; and the UAE was a major financial base for the al-Qaeda terror network. After CFIUS approved the transaction, U.S. politicians and commentators railed and voiced to stop the deal from being completed. Public passions ran high.[14] Congress thereupon overhauled the Committee's review process and passed CFIUS reform legislation - Foreign Investment and National Security Act of 2007 (FINSA).

The DP World case aroused controversies between the Bush Administration and Congress. FINSA is a compromise between them. FINSA makes changes to implicate that Congress will be more involved in the CFIUS review process. Firstly, FINSA statutorily establishes CFIUS as the national security review organ so as to make Congressional supervision easier. Before FINSA, only the President is endowed with the power to supervise the inbound foreign M\&As. The President then delegates the authority to CFIUS through Executive Orders. The presidential designee status makes CFIUS an affiliate of the White House, which is considered as a major disadvantage of the ExonFlorio Amendment, for it weakens the importance of CFIUS and the authority of CFIUS decisions.[15] The establishment of CFIUS independent status indicates that Congress now is able to influence CFIUS decision more easily. Secondly, FINSA requires the chairperson of the Committee to submit an annual report to the chairman and ranking member of the committee of jurisdiction in the Senate and the House of Representative before July 31 each year. The report shall cover all of the reviews and investigations of covered transactions during the previous 12-month period. The change of the quadrennial report into the annual report indicates that Congress has strengthened its oversight of the foreign investment activities in the U.S.

\section{CONGRESS OFTEN DISAPPROVES OF CHINESE CORPORATIONS DURING THE CFIUS REVIEW PROCESS}

It is quite often that Congress takes an adverse position during the national security review process when the covered transactions are from China. Most of time, transactions will fail if Congress votes it down, as what happened in China National Offshore Oil Corporation's (CNOOC) attempted acquisition of Unocal Corporation and Huawei's aborted buying of 3 Leaf System.

When CNOOC offered USD 18.5 billion to buy Unocal, Congress was uneasy and endeavored to persuade the government to stop the transaction due to national security concerns. John W. Snow, the Secretary of the Treasury at the time, told the press that if CNOOC's acquisition proposal was approved by Unocal, the American government would subject the transaction to a national security investigation. [16] Representative William J. Jefferson, with 40 other House members, released a letter requesting CFIUS to review the Chinese company's bid as soon as possible.[17] Later, the House of Representatives approved a resolution demanding a national security review and even passed a law to require an extra review asking the Secretaries of Energy, Defense and Homeland Security to conduct "a wide-ranging examination of China's energy demand and the national security implication to the U.S. of energy assets sought by Chinese companies."'[18] Congressional concerns focused on the oil assets, the deep water drilling high technologies Unocal commanded and the governmental background of CNOOC. Confronting unpredictable Congressional resistance, CNOOC finally abandoned the transaction voluntarily.

In Huawei - 3 Leaf case, CFIUS asked Huawei to divest all the technique assets that belonged to 3 Leaf for the transaction concerns the core technology of cloud computing. Due to the pressure from the government, Huawei finally gave up the transaction. In its open letter to the U.S. government, Huawei tried to clear that it did not have a close tie with Chinese military, and would not steal U.S. confidential information or launch cyber attacks. In the concluding part of the letter, Huawei requested the U.S. to have a fair and just investigation into Huawei so as to clear its name.[19] In response to the open letter, the House Permanent Select Committee on Intelligence started 
a formal investigation, which led to the Investigation Report on the U.S. National Security Issues Posed by Chinese Telecommunications Companies Huawei and ZHE. The report points out that telecommunication closely relates to U.S. nationalsecurity interests and "mitigation measures" is far from enough to clear the threat posed by Chinese telecommunications companies, who are considered to be related to Chinese government and provide equipment and services to U.S. critical infrastructure. The report recommends that CFIUS view from Chinese telecommunications companies' transactions with suspicion, and suggests a potential legislation "to better address the risk posed by telecommunications companies with nation-state ties or otherwise not clearly trusted to build critical infrastructure."'[20]

But there are exceptions once in a while. A good example is Lenovo's buying of IBM PC business. The transaction, too, was questioned by Congress due to its close tie to the Chinese Academy of Sciences, an institution directly supervised by the State Council of China. The case once was worried about to enable the Chinese government to control advanced U.S. technology and corporate assets, and to use the IBM facility for industrial espionage. The transaction therefore was reviewed and investigated by CFIUS. Lenovo and IBM cooperated fully with government agencies so as to get CFIUS approval. With IBM's promise to restrict foreigners from accessing two key buildings at a North Carolina facility to protect related high technological secrets, and with Lenovo's promise to move its operations of the PC unit into a separate facility in IBM's office park in Raleigh, N.C., CFIUS finally approved the transaction.

\section{CHINESE ENTERPRISES NEED TO CHANGE IMAGE TO CLEAR CONGRESSIONAL SUSPICION AND PASS THE NATIONAL SECURITY REVIEW.}

The legislative history of FINSA and precedent cases illustrate that Congress has been gradually developing its influence on the CFIUS review. Congressional influence on the CFIUS review process will keep on increasing in the post financial crisis era. On the other hand, much more investment from China is looking for business opportunities in the U.S. market because of the growth of Chinese economy and Chinese central government's "go abroad" policy. Therefore, there will be more confrontation between Chinese out-bound investors and the U.S. Congress. Understanding and compromise will create win-win business. As for Chinese enterprises, to know and study Congressional role in the CFIUS review will help them to be successful when investing in the U.S. market.

Previous CNOOC, Huawei and Lenovo cases illustrate that Congressional concerns over national security mostly focus on three accounts. First one is the governmental background of the Chinese enterprises. In previous three cases, CNOOC's parent company is wholly controlled by the government, Huawei is considered to have a special relation with the government due to its CEO's military background, and Lenovo's largest shareholder has a close relation with the Chinese State Council. Congress is suspicious of these transactions for they might be part of China's strategy, instead of pure business activities. The second element Congress focuses is the nature of the acquired corporation's assets. In CNOOC case, the target corporation was a major petroleum explorer and marketer. Selling of oil resource may weaken the country's "capability and capacity of domestic industries to meet national defense requirements." In Huawei case, 3 Leaf is a server manufacturer. Its V-8000 Virtual I/O server is considered as a critical technology with potential national securityrelated effects. In Lenovo case, though experts argued that the PC business could not be considered as high technology any more, congress considered it as potentially detrimental to U.S. security for IBM had significant computer contracts with the federal government.[21] The third account is about China's financial support for key corporations and the lack of transparency of corporate structure. In CNOOC case, Congress pointed that $\mathrm{CNOOC}$ obtained extralow-interest loan from state owned banks, and this practice was unfair for its U.S. competitors and had a deleterious effect on U.S. open and free market. In Huawei case, the investigation report pointed out that the corporation lacked transparency on corporate structure and decision-making processes, and it failed to prove its financial independence from Chinese government.

Subsequent Chinese investors need to avoid, as much as possible, previous minefields which may lead to failure of the business. Though public ownership with Chinese characteristics has become a hallmark of Chinese economy, corporations have to follow game rules and be independent when they are doing business internationally. "Guanxi" and hidden rules might be the key to have successful business in China, yet Chinese entrepreneurs need to follow the golden rule - do in Rome as the Romans do - once outside of the territory. In addition, the target corporation's cooperation is helpful to get approved in CFIUS review. Congress may be suspicious of Chinese acquirers out of non-economic reasons, but it will be an impartial observer when explanations are presented by U.S. corporations. The Lenovo case corroborates that a successful transaction requires joint efforts of transaction 
parties. Once a foreign acquirer passes the national security review and establishes a good corporate image, the company will get through CFIUS review much easier in the future. ${ }^{2}$

\section{SUMMARY}

Thanks to the development of domestic economy and the "go abroad" policy, Chinese investment in the U.S. keeps on increasing. The foreign investment national security review is paid close attention to by those who are doing or will do business in the U.S. Congress plays an important role in the establishment and development of the review system. Plenty of precedents indicate that congressional attitude to the covered transaction usually has a substantial influence on the final decision of the CFIUS. As for Chinese investors, it is important to be more independent and transparent in the corporate management so as to get Congressional approval in the CFIUS review.

\section{REFERENCES}

[1] http://www.atkearney.com/documents/10192/4572735/Re ady+for+Takeoff+-+FDICI+2014.pdf/e921968a-5bfe4860-ac51-10ec5c396e95.

[2] Jonathan C. Stagg, Scrutinizing Foreign Investment: How Much Congressional Involvement Is Too Much?, 93 Iowa Law Review 325, 342 (2007).

[3] Paul I. Djuristic. The Exon-Florio Amendment: National Security Legislation Hampered by Political and Economic Forces [J]. DePaul Business \& Commercial Law Journal, 1991 (3): 183.

[4] Ralls Corporation, Appellant v. Committee on Foreign Investment in the United States, et al., Appellees, 758 f.3d 296.

[5] 50 USC App. 2170 (k) (1).

[6] GAO Warns of National Security Impact of ThomsonCSF Acquisition of LTV Missiles, 57 Federal Contracts Report No. 26, at D-12 (Jun. 29, 1992).

[7] Susan J. Tolchin, Halting the Erosion of America's Critical Assets, National Academy of Science Issues in Science \& Technology, Mar. 22, 1993, Vol. V9, No. N3, at 65 .

[8] Thomson-CSF Tries to Restructure LTV Bid, Faces \$ 20 Million Penalty by End of July, 9 International Trade Reporter No.30, at 1269 (Jul. 22, 1992).

[9] Id.

[10] LTV Sues Thomson-CSF for Failure to Pay \$ 20 Million After Bid Withdrawal, 9 International Trade Reporter (BNA) No. 33, at 1359 (Aug. 12, 1992).

[11] Loral Announces Plan to Acquire LTV Missiles, International business Daily (BNA) (Jul. 28, 1992).

[12] Key Senators Oppose Restructured LTV-Thomson Deal, Aerospace Daily, July 7, 1992, Vol. 163, No. 4, at 32.

[13] Deborah M. Mostaghel, Dubai Ports World Under ExonFlorio: A Threat to National Security or a Tempest in a Seaport? 70 Alb. L. Rev. 583, 601 (2007).

2 For example, CFIUS in 2014 once again approved IBM's $\$ 2.3$ billion sale of $\times 86$-based server business to Lenovo.
[14] Alan M. Field, Two Views on CFIUS, Commonwealth Business Media, Aug. 28, 2006.

[15] See Robert N. Cappucci, Note, Amending the Treatment of Defense Production Enterprises Under the U.S. ExonFlorio Provision: A Move Toward Protectionism or Globalism? 16 Fordham int'1 L. J. 652, 675 (1993).

[16] U.S. Government will investigate CNOOC's Unocal Acquisition,

http://finance.sina.com.cn/g/20050624/09581720554.shtm 1 (last visited Sept. 27, 2007).

[17] Jonathan Weisman, In Washington, Chevron Works to Scuttle Chinese Bid, Washington Post, July 16, 2005, at D01. Battling Over China's Bid, Wash Post, Jul. 16, 2005, at D03.

[18] Justin Blum, Legislation Would Require Extra Review of CNOOC Bid, Wash. Post, July 26, 2005, at D02.

[19] Huawei's Open Letter, available at http://wenku.baidu.com/view/f561271859eef8c75fbfb303. html, 2012-9-10, last visited Feb. 7, 2015.

[20] Investigative Report on the U.S. National Security Issues Posed by Chinese Telecommunications Companies Huawei and ZTE, http://www.utdallas.edu/ metin/Or6366/HuaweiZTEInve stigation.pdf, Feb. 6, 2015.

[21] Charles Forelle, Sale of IBM Unit to Chinese Firm Faces U.S. Review, Wall Street Journal, Jan. 28, 2005, at B3. 